\title{
PENGARUH KUALITAS LAYANAN TERHADAP LOYALITAS NASABAH MELALUI CITRA PERUSAHAAN SEBAGAI VARIABEL MEDIASI
}

\author{
I Made Deddy Saputra ${ }^{1}$ \\ I Nyoman Nurcaya ${ }^{2}$ \\ ${ }^{1,2}$ Fakultas Ekonomi dan Bisnis Universitas Udayana (Unud), Bali, Indonesia \\ e-mail: saputradeddy13@yahoo.com
}

\begin{abstract}
ABSTRAK
Kepuasaan nasabah merupakan elemen penting dalam menentukan dan mempertahankan maupun menumbuh kembangkan perusahaan. Untuk dapat mengembangkan loyalitas diantara nasabahnya, bank perlu mengetahui faktor-faktor apa saja yang mempengaruhi loyalitas dan menilai kinerjanya di faktor-faktor tersebut. Penelitian ini dilakukan di kantor pusat PT. BPR Bali Dananiaga Denpasar. Jumlah responden penelitian ini sebanyak 117 responden. Pengumpulan data dilakukan melalui observasi, wawancara dan kuesioner. Penelitian ini menggunakan uji instrumen dengan menggunakan teknik path analysis. Berdasarkan hasil analisis ditemukan bahwa variabel kualitas layanan berpengaruh positif dan signifikan terhadap citra perusahaan. Kualitas layanan berpengaruh positif dan signifikan terhadap loyalitas nasabah. Jadi semakin baik kualitas layanan PT. BPR Bali Dananiaga, maka akan meningkatkan loyalitas nasabah di PT. BPR Bali Dananiaga di Kota Denpasar. Citra perusahaan berpengaruh positif dan signifikan terhadap loyalitas nasabah. Citra perusahaan terbukti mampu memediasi secara positif dan signifikan pengaruh antara kualitas layanan terhadap loyalitas nasabah.
\end{abstract}

Kata Kunci: kualitas layanan, citra perusahaan, loyalitas nasabah

\begin{abstract}
Customer satisfaction is an important element in determining and maintaining and growing the company. To be able to develop loyalty among its customers, banks need to know what factors influence loyalty and assess their performance in these factors. This research was conducted at PT. BPR Bali Dananiaga Denpasar. The number of respondents of this study were 117 respondents. Data collection is done through observation, interview and questionnaire. This research uses instrument test by using path analysis technique. Based on the analysis result found that service quality variable have positive and significant effect to company image. Quality of service has a positive and significant impact on customer loyalty. So the better the service quality of PT. BPR Bali Dananiaga, it will increase customer loyalty in PT. BPR Bali Dananiaga in Denpasar City. Corporate image has a positive and significant impact on customer loyalty. Corporate image proved able to mediate positively and significantly influence between service quality to customer loyalty. Keywords: service quality, corporate image, customer loyalty
\end{abstract}


I Made Deddy Saputra, Pengaruh Kualitas Layanan terhadap...

\section{PENDAHULUAN}

Pada saat ini, perusahaan-perusahaan menghadapi persaingan yang semakin tajam dalam pemasaran produk, baik yang termasuk barang-barang konsumsi maupun barang-barang industri dan jasa. Persaingan ini terutama terdapat dalam kondisi pasar konsumen, dimana konsumen mempunyai peranan yang dominan di pasar sehingga menyebabkan konsumen dianggap raja yang harus dilayani dan dipenuhi kepuasannya atas barang atau jasa yang dikonsumsinya. Salah satu strategi yang saat ini masih dianggap handal yaitu menciptakan layanan terbaik bagi konsumen. Dalam dunia bisnis, khususnya yang bergerak dalam bidang jasa perbankan, kepuasaan nasabah merupakan elemen penting dalam menentukan dan mempertahankan maupun menumbuh kembangkan perusahaan. PT. BPR Bali Dananiaga yang terletak di daerah Gatot Subroto Denpasar Timur merupakan bisnis jasa yang mengutamakan pandangan nasabah terhadap perusahaannya (citra perusahaan), sehingga masalah kualitas layanan (service quality) menjadi faktor penting dalam menentukan keberhasilan bisnis ini terutama meningkatkan loyalitas nasabahnya. Faktor penentu keberhasilan suatu bank sebagai perusahaan jasa dicerminkan dari kemampuan pihak bank dalam memberikan layanan yang berkualitas serta memberikan rasa aman kepada setiap nasabah yang menyimpan dananya di dalam perusahaan. Kualitas layanan adalah ukuran seberapa baik tingkat layanan yang diberikan mampu sesuai dengan apa yang diharapkan konsumen (Tjiptono, 2012:157).

Kualitas layanan suatu bank dapat dilihat melalui bukti fisik berupa fasilitas yang disediakan, layanan yang handal, dan rasa empati yang tinggi. Hilmawan 
(2014) dalam penelitiannya menyatakan kualitas layanan tersebut berpengaruh positif terhadap loyalitas konsumen pada Trans Sarbagita. Hal ini berarti semakin baik layanan yang diberikan terhadap konsumen maka akan meningkatkan loyalitas konsumen. Berbeda dengan penelitian yang dilakukan Hidayat (2010), kualitas layanan berpengaruh tidak signifikan terhadap loyalitas nasabah. Pernyataan ini didukung oleh penelitian yang dilakukan Saputra (2013) yang menyatakan kualitas layanan yang tinggi tidak meningkatkan loyalitas pelanggan. Dalam penelitiannya membuktikan nilai signifikansi tidak searah terhadap loyalitas pelanggan, bahwa kualitas yang baik tidak dapat meningkatkan loyalitas pelanggan. Berdasarkan riset pendahuluan terhadap nasabah PT. BPR Bali Dananiaga dengan melakukan wawancara terhadap 10 nasabah yang melakukan transaksi 3 sampai 4 kali dalam seminggu di Bank tersebut mengenai adakah keluhan yang dirasakan nasabah dari kualitas layanan yang diberikan saat melakukan transaksi dapat dilihat pada Tabel 1 sebagai berikut.

Tabel 1.

\begin{tabular}{clc}
\multicolumn{2}{c}{ Daftar Keluhan Nasabah pada PT. BPR Bali Dananiaga } \\
\hline No & \multicolumn{1}{c}{ Jenis Keluhan } & Jumlah Keluhan \\
\hline 1 & Kecepatan layanan & 5 \\
2 & Ketepatan dalam waktu layanan & 2 \\
3 & Area parkir yang tersedia & 10 \\
4 & Kurangnya ruang tunggu & 7 \\
& Total & 25 \\
\hline
\end{tabular}

Sumber: Nasabah PT. BPR Bali Dananiaga, 2018

Hasil wawancara terhadap 10 nasabah menyatakan 5 dari 10 nasabah mengeluhkan kecepatan layanan saat bertransaksi lambat, 2 dari 10 nasabah mengeluhkan kemampuan karyawan dalam memberikan informasi mengenai proses administrasi, 10 dari 10 nasabah mengeluhkan minimnya area parkir yang tersedia dan 7 dari 10 nasabah menyatakan ruang tunggu yang disediakan masih 
I Made Deddy Saputra, Pengaruh Kualitas Layanan terhadap...

kurang. Keluhan ini harus dipertimbangkan dan segera ditangani oleh perusahaan agar tidak menyebabkan menurunnya loyalitas nasabah maupun citra perusahaan PT. BPR Bali Dananiaga. Data jumlah nasabah PT. BPR Bali Dananiaga dapat dilihat pada Tabel 2 .

Tabel 2.

Jumlah Nasabah PT BPR Bali Dananiaga selama 3 Periode

\begin{tabular}{ccccc}
\hline Jenis & \multicolumn{3}{c}{ Tahun } & Jumlah \\
\cline { 2 - 4 } Produk & $\mathbf{2 0 1 5}$ & $\mathbf{2 0 1 6}$ & $\mathbf{2 0 1 7}$ & \\
\hline Tabungan & 2.587 & 2.478 & 2.514 & 7.579 \\
& $(75,7 \%)$ & $(75,1 \%)$ & $(72,9 \%)$ & \\
Deposito & 494 & 408 & 457 & 1.359 \\
& $(14,4 \%)$ & $(12,4 \%)$ & $(13,2 \%)$ & \\
Kredit & 341 & 411 & 482 & 1.234 \\
& $9,9 \%$ & $(12,5 \%)$ & $(13,9 \%)$ & 10.172 \\
Total & 3.422 & 3.297 & 3.453 & \\
\hline
\end{tabular}

Sumber: PT BPR Bali Dananiaga, 2017

Tabel 2 menunjukkan bahwa adanya ketidakstabilan tingkat nasabah pada jenis produk tabungan, deposito, dan kredit dari tahun 2015-2017. Ketidakstabilan ini dilihat dari presentase pada Tabel 2 dimana pada jenis produk tabungan di tahun 2016-2017 mengalami penurunan sejumlah 2,8\%, kemudian pada tahun 2016 untuk jenis produk deposito juga mengalami penurunan jumlah nasabah sebesar 2,2\%. Hal ini menunjukkan bahwa tingkat loyalitas para nasabah di PT. BPR Bali Dananiaga mengalami ketidakstabilan.

Pramana (2016) menyatakan loyalitas nasabah muncul saat kualitas layanan yang diberikan mampu sesuai apa yang diharapkan nasabah sehingga dapat menimbulkan rasa percaya nasabah terhadap bank tersebut. Nasabah yang merasa puas dan percaya akan kualitas layanan yang diberikan saat bertransaksi yang sesuai dengan harapan nasabah terhadap bank tersebut akan datang kembali untuk melakukan transaksi ulang, dengan begitu akan menimbulkan sikap loyal dari 
nasabah. Menurut Hadiyati (2010) loyalitas nasabah ialah suatu usaha nasabah untuk dapat setia dengan kesan kualitas, kesadaran, kepercayaan, dan mempunyai rasa bangga menggunakan suatu produk/jasa dan akan melakukan pembelian kembali.

Tujuan penelitian ini untuk menjelaskan pengaruh kualitas layanan terhadap citra perusahaan pada PT. BPR Bali Dananiaga Denpasar. Kemudian untuk menjelaskan pengaruh kualitas layanan terhadap loyalitas nasabah pada PT. BPR Bali Dananiaga Denpasar. Untuk menjelaskan pengaruh citra perusahaan terhadap loyalitas nasabah pada PT. BPR Bali Dananiaga Denpasar. Terakhir untuk menjelaskan peran citra perusahaan dalam memediasi pengaruh kualitas layanan terhadap loyalitas nasabah pada PT. BPR Bali Dananiaga Denpasar.

Hasil penelitian ini diharapkan dapat digunakan sebagai bahan dalam menambah wawasan dan pengetahuan serta referensi dalam menambah informasi, dan dapat menjadi sumbangan pemikiran bagi peneliti lain yang akan melakukan penelitian lanjutan mengenai subjek atau objek yang sama. Hasil penelitian ini juga diharapkan dapat menjadi gambaran dan referensi bagi PT. BPR Bali Dananiaga, sebagai bahan pertimbangan dan saran yang membangun dalam pemahaman tentang pengaruh kualitas layanan terhadap citra perusahaan, pengaruh citra perusahaan terhadap loyalitas nasabah serta pengaruh kualitas layanan terhadap loyalitas nasabah.

Kerangka konseptual yang diajukan sebagai dasar penentu hipotesis ditunjukan pada Gambar 1 sebagai berikut. 


\section{Gambar 1. Kerangka Konseptual Penelitian}

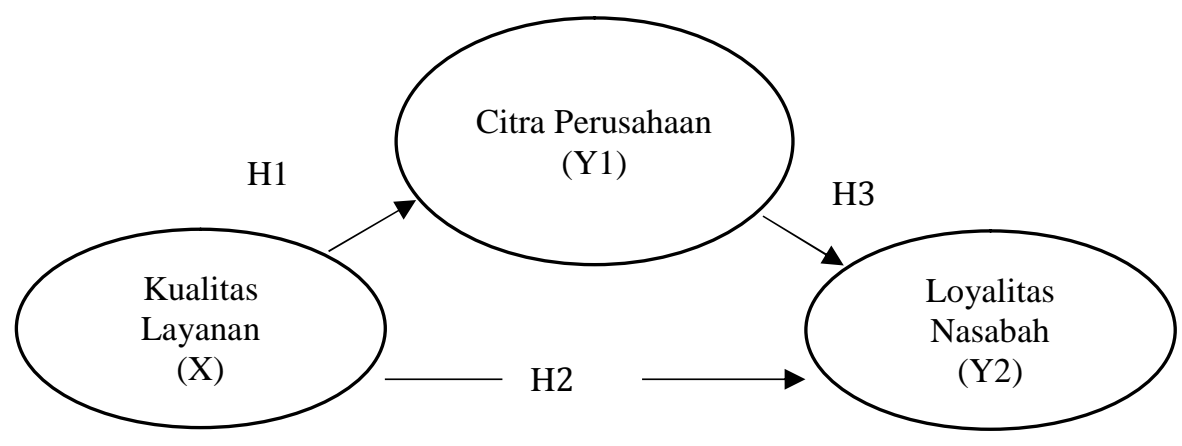

Menurut Normasari dkk. (2013) Citra perusahaan didefinisikan sebagai kesan atau impresi mental atau suatu gambaran dari sebuah perusahaan di mata para khalayaknya yang terbentuk berdasarkan pengetahuan serta pengalaman mereka sendiri. Pramana dan Rastini (2016) mendefinisikan loyalitas nasabah merupakan sebuah usaha nasabah untuk tetap setia dengan kesadaran, kesan kualitas, kepercayaan dan kebanggan, yang kuat terhadap suatu produk.yang dikuti pembelian ulang. Putri (2014) mengungkapkan bahwa pelanggan yang loyal memiliki karakteristik melakukan pembelian berulang secara teratur, membeli antar lini produk dan jasa, mereferensikan kepada orang lain, menunjukan kekebalan terhadap tarikan dari pesaing.

Menurut Kotler (2013:282) mendefinisikan kualitas layanan merupakan totalitas dari bentuk karakteristik barang dan jasa yang menunjukan kemampuannya untuk memuaskan kebutuhan pelanggan, baik yang Nampak jelas maupun yang tersembunyi. Tjiptono dalam Richie Wungow (2013:91) mendefinisikan kualitas layanan dapat diartikan sebagai upaya pemenuhan kebutuhan dan keinginan konsumen serta ketepatan penyampaiannya dalam 
mengimbangi harapan konsumen. Kualitas layanan secara umum adalah lebih menekankan pada kata pelanggan, layanan, kualitas dan level atau tingkat.

Kualitas layanan berpengaruh positif terhadap citra perusahaan, ini dikemukakan oleh hasil penelitian terdahulu yang dilakukan Handi (2013). Ini berarti jika kualitas layanan mengalami peningkatan maka secara tidak langsung citra dari suatu perusahaan juga akan meningkiat begitu pula sebaliknya Berdasarkan dari hasil penelitian sebelumnya, maka pada penelitian ini dapat ditarik hipotesis sebagai berikut:

$\mathrm{H}_{1}$ : Kualitas layanan berpengaruh positif dan signifikan terhadap citra perusahaan Kemudian pengaruh positif juga terdapat dalam hubungan antara kualitas layanan terhadap loyalitas nasabah, hal ini sejalan dengan penelitian yang dilakukan oleh Mosahab et al. (2010). Hal ini juga sejalan dengan hasil penelitian yang dilakukan oleh Arab et al. (2012) yang menyatakan dalam penelitiannya yakni kualitas layanan berpengaruh positif terhadap loyalitas pelanggan. Berdasarkan dari hasil penelitian sebelumnya, maka pada penelitian ini dapat ditarik hipotesis sebagai berikut:

$\mathrm{H}_{2}$ : Kualitas layanan berpengaruh positif dan signifikan terhadap loyalitas nasabah.

Hasil penelitian terdahulu dilakukan oleh Anggrayana dan Pramudana (2013) menyatakan bahwa kualitas layanan memiliki pengaruh positif dan signifikan terhadap loyalitas pelanggan, hal ini berarti semakin baik kualitas layanan yang diberikan maka loyalitas pelanggan akan mengalami peningkatan. Berdasarkan dari hasil penelitian sebelumnya, maka pada penelitian ini dapat ditarik hipotesis sebagai berikut: 
I Made Deddy Saputra, Pengaruh Kualitas Layanan terhadap...

$\mathrm{H}_{3}$ : Citra perusahaan berpengaruh positif dan signifikan terhadap loyalitas nasabah

Penelitian yang dilakukan oleh Widiyanto dan Juan Suam Toro (2012), Farida (2013), Pemayuni dan Wulandari (2015), Pratama dan Nyoman Nurcaya (2016) serta Boon-Liat Cheng dan Zabid (2013) menyatakan bahwa citra perusahaan mampu memediasi secara positif dan signifikan terhadap suatu variable. Berdasarkan dari hasil penelitian sebelumnya, maka pada penelitian ini dapat ditarik hipotesis sebagai berikut:

$\mathrm{H}_{4}$ : Citra perusahaan berpengaruh positif dan signifikan dalam memediasi kualitas layanan dengan loyalitas nasabah.

\section{METODE PENELITIAN}

Berdasarkan permasalahan yang diteliti, penelitian ini digolongkan pada penelitian asosiatif (hubungan), yaitu suatu penelitian yang bertujuan untuk mengetahui pengaruh sebab akibat dari variabel yang diteliti (Sugiyono, 2013:37). Untuk mendapatkan hasil penelitian yang baik, maka dibutuhkan desain penelitian untuk menunjang dan memberikan hasil penelitian yang sistematik. Penelitian ini menggunakan teknik analisis berupa path analysis (analisis jalur) dan uji sobel serta bertujuan untuk mencari tahu pengaruh dari kualitas layanan terhadap loyalitas nasbah melalui citra perusahaan sebagai variabel mediasi.

Ruang lingkup wilayah penelitian ini dilaksanakan di kantor pusat PT. BPR Bali Dananiaga Jalan Gatot Subroto Timur no. 332 Denpasar. Lokasi ini dipilih karena terdapat jumlah nasabah terbanyak dan untuk dapat membantu memecahkan masalah mengenai loyalitas nasabah, agar dapat mengetahui penyebab dan faktor-faktor apa saja yang menyebabkan nasabah menjadi loyal 
terhadap perusahaan sehingga perusahaan dapat meningkatkan kualitasnya dan loyalitas nasabahnya pun dapat ditingkatkan.

Objek yang digunakan dalam penelitian ini adalah kualitas layanan (X) terhadap loyalitas nasabah $\left(\mathrm{Y}_{1}\right)$ melalui citra perusahaan sebagai variable mediasi $\left(\mathrm{Y}_{2}\right)$ pada PT. BPR Bali Dananiaga. Populasi dalam menelitian ini adalah seluruh nasabah PT. BPR Bali Dananiaga. Sampel dalam penelitian ini adalah nasabah PT BPR Bali Dananiaga Denpasar selama 3 tahun terakhir yang berdomisili di Kota Denpasar dan memiliki pendidikan minimal SMA/Sederajat. Penentuan sampel dalam penelitian ini menggunakan metode probability sampling yakni teknik pengambilan sampel yang memberi peluang / kesempatan yang sama bagi setiap unsur atau anggota populasi untuk dipilih menjadi sampel (Sugiyono, 2013: 85). Teknik nonprobability sampling yang dipilih adalah accidental sampling yaitu teknik penentuan sampel berdasarkan faktor sponantanitas, artinya siapa saja yang tidak sengaja bertemu dengan peneliti dan sesuai dnegan karakteistik maka orang tersebut dapat digunakan sebagai sampel (responden).

Pemilihan berdasarkan tingkat pendidikan dan adanya batasan kurun waktu, dianggap dapat menjawab pertanyaan yang diajukan dalam penelitian. Untuk memperoleh data yang valid, maka jumlah sampel responden yang diambil dan ditentukan paling sedikit 5-10 kali jumlah indikator (Ferdinand, 2015:5). Jumlah dari sampel responden yang akan diuji di dapat dari hasil perhitungan sebagai berikut:

$$
\begin{aligned}
\text { Jumlah Responden } & =\text { Jumlah indikator } \mathrm{x} 7 \\
& =16 \text { indikator } \mathrm{x} 7
\end{aligned}
$$


I Made Deddy Saputra, Pengaruh Kualitas Layanan terhadap...

$$
=117 \text { responden }
$$

Dari perhitungan diatas, maka didapat bahwa jumlah sampel minimal yang harus digunakan dalam penelitian ini adalah 100, sebab menurut Sugiyono (2013:80) sampel penelitian dapat dikatakan valid, apabila penelitian tersebut memiliki minimal 100 responden, sehingga sampel dalam penelitian ini sudah bisa dikatakan valid.

Metode pengumpulan data untuk penelitian ini adalah dengan menggunakan metode survey yakni dengan kuesioner. Kuesioner disebarkan ke nasabah BPR Bali Dananiaga yang sedang melakukan transaksi ataupun sedang berada di BPR Bali Dananiaga Denpasar dan pengisiannya di dampingi oleh peneliti. Pengukuran atas jawaban dari responden diukur dengan menggunakan skala Likert.

Zeithml dan Britner (2013) mendefinisikan kualitas layanan merupakan totalitas dari bentuk karakteristik suatu barang dan jasa yang menunjukan kemampuannya untuk memuaskan kebutuhan pelanggan dan mengemukakan bahwa terdapat lima dimensi mengenai kualitas layanan dengan 10 indikator meliputi 1). Fasilitas fisik, wujudnya brupa segala fasilitas yang secara nyata dapat terlihat yang ada di BPR Bali Dananiaga; 2). Kelengkapan sarana komunikasi yang ada di BPR Bali Dananiaga; 3). Ketepatan waktu, yaitu memberikan pelayanan yang dibutuhkan nasabah BPR Bali Dananiaga dan menyelesaikannya dengan cepat; 4). Kecakapan layanan, merupakan sikap tangga dari petugas BPR Bali Dananiaga dalam pemberian layanan yang dibutuhkan; 5). Tanggap dalam masalah, yaitu tanggap dalam menanggapi keluhan nasabah BPR 
Bali Dananiaga; 6). Waktu penyelesaian masalah, yaitu kemampuan BPR Bali Dananiaga untuk menyelesaikan masalah tepat waktu dengan pengerjaan yang benar; 7). Kemampuan, yaitu upaya perlindungan yang mampu diberikan perusahaan kepada nasabah BPR Bali Dananiaga; 8). Kesopanan, yaitu sifat yang harus dimiliki karyawan BPR Bali dananiaga untuk meningkatkan kualitas layanan; 9). Kemudahan hubungan komunikasi, yaitu layanan yang diberikan kepada nasabah BPR Bali Dananiaga untuk mendengarkan keluhan nasabah; 10). Memahami kebutuhan nasabah, yaitu perhatian yang diberikan perusahaan kepada nasabah BPR Bali Dananiaga dengan menempatkan dirinya pada situasi pelanggan.

Menurut Sari (2014) citra perusahaan didefinisikan sebagai kesan atau impresi mental atau suatu gambaran dari sebuah perusahaan di mata para khalayaknya yang terbentuk berdasarkan pengetahuan serta pengalaman mereka sendiri informasi lengkap mengenai citra perusahaan mempunyai 3 indikator, yaitu: 1). Reputasi, yaitu hal yang sudah diyakini publik sasaran BPR Bali Dananiaga berdasarkan pengalaman sendiri maupun pihak lain; 2). Nilai, yaitu budaya yang dimiliki BPR Bali Dananiaga seperti kepedulian terhadap nasabah, cepat tanggap terhadap keluhan nasabah.; 3). Identitas perusahaan, yaitu komponen yang mempermudah pengenalan publik sasaran terhadap BPR Bali Dananiaga. Contoh: logo, warna dan simbol.

Menurut Kertajaya (2013) mengungkapkan bahwa pelanggan yang loyal memiliki karakteristik melakukan pembelian berulang secara teratur dan membeli antar lini produk dan jasa, mereferensikan kepada orang lain dan mengatakan 
I Made Deddy Saputra, Pengaruh Kualitas Layanan terhadap...

bahwa terdapat 3 indikator loyalitas, yaitu 1). Banyaknya transaksi, yaitu mengukur kebiasaan nasabah BPR Bali Dananiaga dalam melakukan transaksi; 2). Merekomendasikan kepada oranglain, yaitu mengukur keterlibatan emosional nasabah BPR Bali Dananiaga berdasarkan kesediaannya merekomendasikan BPR Bali Dananiaga kepada orang lain; 3). Antusias terhadap produk baru, yaitu mengukur tingkat retensi nasabah berdasarkan antusias terhadap produk baru BPR Bali Dananiaga dengan pengalaman lama menggunakan jasa nasabah.

Tabel 3.

Definisi Operasional Variabel Penelitian

\begin{tabular}{|c|c|c|}
\hline Variabel & Indikator & Sumber \\
\hline $\begin{array}{l}\text { Kualitas layanan } \\
\text { (X) }\end{array}$ & $\begin{array}{l}\text { 1. fasilitas fisik } \\
\text { 2. Kelengkapan sarana komunikasi } \\
\text { 3. Ketepatan waktu } \\
\text { 4. Kecakapan layanan } \\
\text { 5. Tanggap dalam masalah } \\
\text { 6. Waktu penyelesaian masalah } \\
\text { 7. Kemampuan } \\
\text { 8. Kesopanan } \\
\text { 9. Kemudahan hubungan komunikasi } \\
\text { 10. Memahami kebutuhan nasabah }\end{array}$ & $\begin{array}{l}\text { Zeithml dan Bitner } \\
\text { (2013) }\end{array}$ \\
\hline $\begin{array}{l}\text { Citra perusahaan } \\
\text { (Y1) }\end{array}$ & $\begin{array}{ll}\text { 1. } & \text { Reputasi } \\
\text { 2. Nilai } \\
\text { 3. } & \text { Identitas Perusahan }\end{array}$ & Sari (2014) \\
\hline $\begin{array}{l}\text { Loyalitas } \\
\text { Nasabah } \\
\text { (Y2) }\end{array}$ & $\begin{array}{l}\text { 1. Banyaknya transaksi } \\
\text { 2. Merekomendasikan kepada orang } \\
\text { lain } \\
\text { 3. Antusias terhadap produk baru }\end{array}$ & Kertajaya (2013) \\
\hline
\end{tabular}

Sumber: Data sekunder, 2018

Penelitian ini menggunakan uji instrumen terlebih dahulu kemudian dilakukan uji asumsi klasik. Analisis jalur merupakan teknik model analisis yang digunakan untuk menganalisis pola hubungan antar variabel dengan tujuan untuk mengetahui pengaruh langsung maupun tidak langsung seperangkat variabel bebas terhadap variabel terikat. Masing - masing hipotesis memiliki persamaan struktural yang berbeda sebagai berikut: 
$\mathrm{Y}_{1}=\beta_{1} \mathrm{X}+\mathrm{e}_{1}$

Keterangan:

$\mathrm{B}_{1} \quad=$ koefisien jalur dari kualitas layanan

$\mathrm{X} \quad=$ kualitas layanan

$\mathrm{Y}_{1} \quad=$ citra perusahaan

$\mathrm{e}_{1} \quad=$ nilai kekeliruan taksiran standar

$\mathrm{Y}_{2}=\beta_{2} \mathrm{X}+\beta_{3} \mathrm{Y}_{1}+\mathrm{e}_{2}$

Keterangan:

$\mathrm{Y}_{2} \quad=$ loyalitas nasabah

$\mathrm{B}_{2} \quad=$ koefisien jalur dari kualitas layanan

$\beta_{3}=$ koefisien jalur dari citra perusahaan

$\mathrm{X} \quad=$ kualitas layanan

$\mathrm{Y}_{1} \quad=$ citra perusahaan

$\mathrm{e}_{2}=$ nilai kekeliruan taksiran standar

\section{PEMBAHASAN}

PT. Bank Perkreditan Rakyat Bali Dananiaga yang sebelumnya bernama Kertiawan Dananiaga didirikan berdasarkan Akta Notaris No. 78 tanggal 8 Desember 1992. PT BPR Bali Dananiaga sendiri sudah memiliki kantor kas yang beralamat: Jl. Teuku Umar no.8 (kawasan niaga B) serta memiliki dua cabang yang masing masing yang beralamat Jl. Agung Mandera (Br. Teges Kangin), Peliatan Ubud dan J1. By Pass Ngurah Rai No.98b, Jimbaran - Kuta.

Struktur organisasi PT. BPR Bali Dananiaga terdiri atas RUPS, Dewan Komisaris, dan Dewan Direksi yang bertanggung jawab atas PE Audit Intern, PE Kabag Dana, PE Kabag Kredit, PE Kabag Operasional dan PE Kepatuhan. Masing-masing PE Kabag saling berkoordinasi. PE Kabag Dana bertanggung jawab atas Admin Dana, Marketing Dana, dan Teller lapangan kemudian PE Kabag Kredit bertanggung jawab atas analis kredit, admin kredit, Appraisal, legal, ARM, dan marketing dana. PE Kabag Operasional bertanggung jawab atas 
I Made Deddy Saputra, Pengaruh Kualitas Layanan terhadap...

MSDM/HRD, sekretaris, Kantor kas dan kantor cabang, Customer Service, teller, Accounting, IT, Bagian umum, Satpam, Sopir, dan office boy/girl.

Jumlah responden dalam penelitian ini adalah 117 orang. Responden pada penelitian di PT. BPR Bali Dananiaga Denpasar dominan berusia 31 sampai 40 tahun, dengan persentase sebesar 41,03 persen. Hal ini menandakan nasabah usia 31 sampai 40 tahun lebih banyak menggunakan jasa bank PT. BPR Bali Dananiaga karena pada usia 31 sampai 40 tahun kebanyakan responden sudah menjadi pegawai tetap dan sudah menikah sehingga perlu menabung untuk berjaga-jaga terhadap kebutuhan yang tidak terduga.

Dilihat dari segi jenis kelamin, responden didominasi oleh jenis kelamin perempuan dengan persentase 61,50 persen yaitu berjumlah 72 orang. Hal ini menandakan responden dengan jenis kelamin perempuan lebih banyak menggunakan jasa bank PT. BPR Bali Dananiaga, disamping perempuan lebih banyak memiliki kebutuhan, perempuan juga lebih banyak berwirausaha sehingga menjadi nasabah bank perlu dilakukan untuk memenuhi kebutuhan dan menunjang lifestyle.

Sebagian besar nasabah PT. BPR Bali Dananiaga Denpasar mengenyam pendidikan terakhir Sarjana yaitu sebanyak 58 orang dengan persentase 49,57 persen. Hal ini menandakan responden dengan pendidikan terakhir Sarjana lebih loyal dalam menggunakan jasa bank PT. BPR Bali Dananiaga. Nasabah yang bekerja sebagai pengusaha/wiraswasta mendominasi dengan jumlah karyawan 68 orang dengan persentase 58,12. Hal ini menandakan bahwa responden yang lebih loyal menggunakan jasa bank PT. BPR Bali Dananiaga adalah responden dengan 
pekerjaan sebagai pengusaha/wiraswasta karena selain untuk memenuhi kebutuhan hidup maupun usahanya, dapat menunjang karirnya sebagai pengusaha.

Pertama dilakukan uji instrumen yakni uji validitas bertujuan untuk menilai instrumen yang digunakan telah tepat untuk mengukur indikator dalam penelitian. Hasil pengukuran validitas masing - masing instrumen pada variabel disajikan dalam Tabel 4 sebagai berikut.

Tabel 4.

Hasil Uji Validitas

\begin{tabular}{cccc}
\hline Variabel & Instrumen & Pearson Correlation & Keterangan \\
\hline & X.1 & 0,578 & Valid \\
& X.2 & 0,627 & Valid \\
& X.3 & 0,809 & Valid \\
Kualitas Layanan & X.4 & 0,877 & Valid \\
(X) & X.6 & 0,757 & Valid \\
& X.7 & 0,556 & Valid \\
& X.8 & 0,746 & Valid \\
& X.9 & 0,722 & Valid \\
Citra Perusahaan & X.10 & 0,583 & Valid \\
(Y1) & Y1.1 & 0,467 & Valid \\
& Y1.3 & 0,940 & Valid \\
Loyalitas Nasabah & Y2.1 & 0,899 & Valid \\
(Y2) & Y2.2 & 0,878 & Valid \\
& Y2.3 & 0,874 & Valid \\
& 0,897 & Valid \\
\hline
\end{tabular}

Sumber: Data diolah, 2018

Hasil uji validitas instrumen penelitian disajikan pada Tabel 4 yang menunjukkan bahwa seluruh indikator dalam variabel kualitas layanan, citra perusahaan, dan loyalitas nasabah memiliki nilai Pearson Correlation yang lebih besar dari angka 0,30 sehingga seluruh indikator tersebut dikatakan telah memenuhi syarat validitas data. 
I Made Deddy Saputra, Pengaruh Kualitas Layanan terhadap...

Uji Reliabilitas bertujuan untuk mengukur konsistensi alat ukur yang digunakan. Hasil pengukuran reliabilitas masing-masing variabel disajikan dalam Tabel 4 sebagai berikut.

Tabel 5.

Hasil Uji Reabilitas

\begin{tabular}{ccc}
\hline Variabel & Cronbach'sAlpha & Keterangan \\
\hline Kualitas Layanan (X) & 0,864 & Reliabel \\
Citra Perusahaan (Y1) & 0,884 & Reliabel \\
Loyalitas Nasabah (Y2) & 0,858 & Reliabel \\
\hline
\end{tabular}
Sumber: Data diolah, 2018

Hasil uji reliabilitas instrumen pada penelitian ini disajikan pada Tabel 5 yang menunjukkan bahwa ketiga instrumen penelitian yaitu variabel kualitas layanan, citra perusahaan, dan loyalitas nasabah memiliki koefisien cronbach's alpha yang lebih besar dari angka 0,60 sehingga pernyataan pada kuesioner dapat dikatakan reliabel dan indikator yang digunakan merupakan indikator yang konsisten.

Penelitian ini menggunakan Analisis Jalur (Path Analysis) sebagai metode penelitiannya. Metode ini merupakan perluasan dari metode regresi linear berganda untuk menguji hubungan kausalitas antar dua variabel atau lebih. Berikut penjelasan lebih rinci mengenai tahapan dalam pengujian analisis jalur:

$$
\text { Struktur : } \mathrm{Y}_{1}=\beta_{1} \mathrm{X}
$$

$$
\begin{array}{ll}
\mathrm{Y}_{1} & =0,455 \mathrm{X} \\
\mathrm{Se} & =0,034 \\
\mathrm{t} & =5,484 \\
\text { Sig } \mathrm{t} & =0,000 \\
\text { Sig } \mathrm{F} & =0,000 \\
\mathrm{R}^{2} & =0,207 \\
\mathrm{~F} & =30,078
\end{array}
$$

Dari persamaan regresi tersebut, dapat ditulis persamaan struktural 1 , yaitu sebagai berikut: 


$$
\mathrm{Y}_{1}=0,455 \mathrm{X}
$$

Berdasarkan hasil analisis persamaan regresi satu, didapat bahwa nilai Kolmogorv - smirnov $(K-S)$ sebesar 1,030 kemudian nilai Asymp. Sig (2-tailed) sebesar 0,240, maka hasil tersebut menandakan bahwa model persamaan regresi tersebut berdistribusi normal karena, nilai Asymp. Sig (2-tailed) 0,240 lebih besar dari nilai alpha 0,05.Hasil analisis persamaan regresi satu, nilai tolerance dari variabel kualitas layanan sebesar 1.000 yaitu lebih besar dari 10 persen, kemudian nilai VIF variabel kualitas layanan lebih kecil dari 10. Hal tersebut menandakan bahwa model persamaan regresi 1 bebas dari multikoloniearitas.

Berdasarkan hasil analisis regresi satu, dapat dilihat bahwa Sig. dari variabel kualitas layanan sebesar 0,057 lebih besar dari 0,05. Artinya tidak terdapat pengaruh antara variabel bebas terhadap absolute residual sehingga model yang dibuat tidak mengandung gejala heterokedastisitas. Hasil pengujian Sig. F pada persamaan regresi 1 , dapat dilihat Sig. F $<0,05(0,000<0,05)$ maka $\mathrm{H}_{1}$ diterima yaitu kualitas layanan berpengaruh secara signifikan terhadap citra perusahaan. Maka dapat diambil kesimpulan bahwa model persamaan struktural telah memenuhi syarat goodness of fit melalui uji $\mathrm{F}$.

Persamaan regresi struktural 2, dilaporkan sebagai berikut:

$$
\begin{aligned}
& \text { Struktur: } Y_{2}=\beta_{2} X+\beta_{3} Y_{1} \\
& \mathrm{Y}_{2}=0,339 \mathrm{X}+0,526 \mathrm{Y}_{1} \\
& \mathrm{Se} \quad=(0,027) \quad(0,066) \\
& \mathrm{t} \quad=(4,814) \quad(7,475) \\
& \text { Sig } \mathrm{t}=0,000 \\
& \text { Sig. F }=0,000 \\
& \mathrm{R}^{2}=0,553 \\
& \mathrm{~F} \quad=70,530
\end{aligned}
$$


I Made Deddy Saputra, Pengaruh Kualitas Layanan terhadap...

Berdasarkan hasil analisis persamaan regresi dua, didapat bahwa nilai Kolmogorv - smirnov (K-S) sebesar 1,144 kemudian nilai Asymp. Sig. (2-tailed) 0,120 lebih besar dari nilai alpha 0,05 . Berdasarkan hasil analisis persamaan regresi dua, nilai tolerance dari variabel kualitas layanan dan citra perusahaan sama-sama sebesar 0,793 yang lebih besar dari 10 persen, kemudian nilai VIF variabel kualitas layanan dan citra perusahaan sama-sama sebesar 1,262 lebih kecil dari 10. Hal tersebut menandakan bahwa model persamaan regresi 2 bebas dari multikoloniearitas.

Berdasarkan hasil analisis persamaan regresi dua,dapat dikatakan bahwa nilai signifikansi dari variabel kualitas layanan yaitu sebesar 0,170 kemudian variabel citra perusahaan sebesar 0,677. Nilai signifikansi dari kedua variabel tersebut lebih besar dari 0,05 berarti tidak terdapat pengaruh antara variabel bebas terhadap absolute residual, hal tersebut menandakan bahwa model yang dibuat tidak terdapat gejala heteroskedastisitas. Hasil pengujian Sig. F pada persamaan regresi 1 , dapat dilihat Sig. $\mathrm{F}<0,05(0,000<0,05)$ maka $\mathrm{H}_{1}$ diterima yaitu kualitas layanan berpengaruh secara signifikan terhadap loyalitas nasabah. Maka dapat diambil kesimpulan bahwa model persamaan struktural telah memenuhi syarat goodness of fit melalui uji $\mathrm{F}$.

Hasil dari pengaruh langsung, tidak langsung dan pengaruh total dijabarkan pada tabel 6 sebagai berikut: 
Tabel 6.

Pengaruh Langsung dan Pengaruh Tidak Langsung serta Pengaruh Total

\begin{tabular}{llll}
\hline $\begin{array}{c}\text { Pengaruh } \\
\text { Variabel }\end{array}$ & \multicolumn{1}{c}{$\begin{array}{c}\text { Pengaruh } \\
\text { Langsung }\end{array}$} & \multicolumn{1}{c}{$\begin{array}{c}\text { Pengaruh Tidak Langsung } \\
\text { Melalui Mediasi }\end{array}$} & Pengaruh Total \\
\hline $\mathrm{X} \rightarrow$ Y1 & 0,455 & - & 0,455 \\
$\mathrm{X} \rightarrow$ Y2 & 0,339 & 0,239 & 0,578 \\
Y1 $\rightarrow$ Y2 & 0,526 & - & 0,526 \\
\hline Sumber: & Data diolah, 2018 & &
\end{tabular}

Hasil koefisien pengaruh tidak langsung lebih kecil dibandingkan pengaruh langsung $(0,239<0,339)$, sehingga dapat dikatakan bahwa variabel citra perusahaan adalah sebagai variabel mediasi dalam memediasi pengaruh variabel kualitas layanan tehadap variabel loyalitas nasabah.

Berdasarkan model substruktural 1 dan substruktural 2, maka dapat disusun model diagram jalur akhir. Sebelum menyusun model diagram jalur akhir, terlebih dahulu dihitung nilai standar error sebagai berikut.

$$
\begin{aligned}
& \mathrm{Pe}_{\mathrm{i}}=\sqrt{1-\mathrm{Ri}^{2}} \\
& \mathrm{Pe}_{1}=\sqrt{1-\mathrm{R}_{1}^{2}}=\sqrt{1-0,207}=0,890 \\
& \mathrm{Pe}_{2}=\sqrt{1-\mathrm{R}_{2}^{2}}=\sqrt{1-0,553}=0,668
\end{aligned}
$$

Berdasarkan perhitungan nilai standar eror, didapatkan hasil $\mathrm{Pe}_{1}$ sebesar 0,890 dan $\mathrm{Pe}_{2}$ sebesar 0,668. Hasil koefisien determinasi total dihitung sebagai berikut:

$$
\begin{aligned}
\mathrm{R}^{2} \mathrm{~m} & =1-\left(\mathrm{Pe}_{1}\right)^{2}\left(\mathrm{Pe}_{2}\right)^{2} \ldots \ldots \\
& =1-(0,890)^{2}(0,668)^{2} \\
& =0,471
\end{aligned}
$$

Nilai determinasi total sebesar 0,471 memiliki arti bahwa sebesar $47,1 \%$ variasi loyalitas nasabah dipengaruhi oleh variasi kualitas layanan dan citra 
I Made Deddy Saputra, Pengaruh Kualitas Layanan terhadap...

perusahaan, sedangkan sisanya sebesar $52,9 \%$ dijelaskan oleh faktor-faktor lain yang tidak dimasukkan ke dalam model penelitian.

Uji sobel dilakukan dengan cara menguji kekuatan pengaruh tidak langsung variabel bebas (X) ke variabel terikat (Y) melalui variabel mediasi (M). Menguji signifikansi pengaruh tidak langsung kualitas layanan dengan loyalitas nasabah melalui citra perusahaan, maka dapat dipergunakan persamaan dengan substitusi nilai:

$\mathrm{a} \quad=0,455 ; \mathrm{S}_{\mathrm{a}}=0,034 ; \mathrm{b}=0,526 ; \mathrm{S}_{\mathrm{b}}=0,066$

Maka didapat nilai $\mathrm{z}$ hitung $=6,8333$

Jika nilai z hitung lebih besar dari z tabel, maka dapat disimpulkan terjadi pengaruh mediasi. Berdasarkan perhitungan, didapatkan nilai z hitung sebesar 6,8333 yang artinya lebih besar dari z tabel yaitu 1,9812. Dapat disimpulkan bahwa citra perusahaan mampu memediasi pengaruh kualitas layanan terhadap loyalitas nasabah. Mediasi yang terjadi adalah mediasi parsial karena hubungan kualitas layanan terhadap citra perusahaan signifikan dan dari citra perusahaan ke loyalitas nasabah juga tetap signifikan.

Berdasarkan hasil analisis pengaruh Kualitas Layanan terhadap Citra Perusahaan diperoleh nilai koefisien beta sebesar 0,455 dengan tingkat signifikansi sebesar 0,000 ( $₫, 05)$ yang berarti $\mathrm{H}_{0}$ ditolakdan $\mathrm{H}_{1}$ diterima. Hasil tersebut berarti bahwa variabel kualitas layanan berpengaruh positif dan signifikan terhadap citra perusahaan. Jadi semakin baik kualitas layanan PT. BPR Bali Dananiaga, maka akan meningkatkan citra perusahaan PT. BPR Bali Dananiaga di Kota Denpasar. Hasil penelitian ini sejalan dengan hasil penelitian sebelumnya 
yang dilakukan oleh Handi (2013) yang melaporkan bahwa Kualitas Layanan berpengaruh positif dan signifikn terhadap Citra Perusahaan.

Berdasarkan hasil analisis pengaruh Kualitas Layanan terhadap Loyalitas nasabah diperoleh nilai koefisien beta sebesar 0,339 dengan tingkat signifikansi sebesar 0,000 ( $₫, 05)$ yang berarti $\mathrm{H}_{0}$ ditolakdan $\mathrm{H}_{1}$ diterima. Hasil tersebut berarti bahwa variabel kualitas layanan berpengaruh positif dan signifikan terhadap loyalitas nasabah. Jadi semakin baik kualitas layanan PT. BPR Bali Dananiaga, maka akan meningkatkan loyalitas nasabah di PT. BPR Bali Dananiaga di Kota Denpasar. Hasil penelitian ini sejalan dengan hasil penelitian sebelumnya yang dilakukan oleh Mosahab et al. (2010) dan Arab et al. (2012) yang berpendapat bahwa ada pengaruh yang positif antara kualitas layanan terhadap loyalitas nasabah.

Hasil analisis Pengaruh Citra Perusahaan terhadap Loyalitas nasabah diperoleh nilai koefisien beta sebesar 0,526 dengan tingkat signifikansi sebesar $0,000(\unlhd, 05)$ yang berarti $\mathrm{H}_{0}$ ditolakdan $\mathrm{H}_{1}$ diterima. Hasil tersebut berarti bahwa variabel citra perusahaan berpengaruh positif dan signifikan loyalitas nasabah. Jadi semakin bagus citra PT. BPR Bali Dananiaga dimata nasabah, maka akan meningkatkan loyalitas nasabah di PT. BPR Bali Dananiaga. Hasil penelitian ini sejalan dengan hasil penelitian sebelumnya yang dilakukan oleh Anggrayana dan Pramudana (2013) yang melaporkan bahwa Citra perusahaan berpengaruh positif dan signifikan terhadap Loyalitas nasabah.

Pengujian hipotesis pada peran citra perusahaan dalam Memediasi Kualitas Layanan terhadap Loyalitas Nasabah PT. BPR Bali Dananiaga dengan 
I Made Deddy Saputra, Pengaruh Kualitas Layanan terhadap...

menggunakan uji Sobel membuktikan Peran Citra Perusahaan secara signifikan memediasi pengaruh kualitas layanan terhadap Loyalitas nasabah dengan hasil Z $=6,8333>1,9812$ dengan tingkat signifikansi $0,000<0,05$.

Hasil penelitian ini didukung oleh penelitian sebelumnya yang dilakukan oleh Widiyanto dan Juan Suam Toro (2012), Farida (2013), Pemayuni dan Wulandari (2015), Pratama dan Nyoman Nurcaya (2016) serta Boon-Liat Cheng dan Zabid (2013) yang menyatakan bahwa citra perusahaan mampu memediasi secara positif dan signifikan terhadap suatu variable. Pada penelitian ini, ditemukan bahwa citra perusahaan terbukti mampu memediasi secara positif dan signifikan pengaruh antara kualitas layanan terhadap loyalitas nasabah.

Implikasi penelitian menekankan pada manfaat nyata dari hasil penelitian ini bagi pihak-pihak yang berkepentingan khususnya bagi PT. BPR Bali Dananiaga. PT. BPR Bali Dananiaga sebaiknya mempertahankan citra perusahaan yang baik dan kualitas layanan yang diberikan. Terbukti dari hasil penelitian yang diperoleh dan pemaparan atas keterkaitan antar variabel yang secara umum memiliki pengaruh yang positif dan signifikan. Pertama, loyalitas nasabah akan tercipta karena kualitas layanan yang positif. Persepsi baik yang timbul terhadap kualitas layanan PT. BPR Bali Dananiaga akan meningkatkan loyalitas nasabah. PT. BPR Bali Dananiaga harus mempertahankan citra perusahaan yang baik, serta terus melakukan inovasi agar dapat bersaing dengan bank-bank lainnya.

Implikasi kedua yaitu, loyalitas nasabah dapat meningkat karena kualitas layanan yang baik serta persepsi citra perusahaan yang positif tertanam di benak nasabah. PT. BPR Bali Dananiaga sebagai perusahaan jasa perlu mempertahankan 
kualitas layanan yang baik serta menanamkan citra perusahaan yang baik, dimana citra perusahaan dapat menjembatani pengaruh antara kualitas layanan terhadap loyalitas nasabah sehingga semakin baik kualitas layanan dan semakin kuat citra perusahaan yang tertanam di benak nasabah akan mempengaruhi loyalitasnya terhadap perusahaan. Selain melalui citra perusahaan, loyalitas juga dipengaruhi secara langsung oleh kualitas layanan. Ketiga variabel yang diteliti memiliki keterkaitan satu sama lain sehingga PT. BPR Bali Dananiaga perlu memperhatikan persepsi tentang kualitas layanan serta tetap menjaga citra perusahaan yang baik dimata nasabah sehingga loyalitas mereka terhadap perusahaan akan meningkat.

\section{SIMPULAN DAN SARAN}

Berdasarkan pembahasan hasil penelitian yang telah dilakukan, maka dapat disimpulkan bahwa: 1). Kualitas layanan berpengaruh positif dan signifikan terhadap citra perusahaan. Hal ini berarti semakin baik kualitas layanan PT. BPR Bali Dananiaga, maka akan meningkatkan citra perusahaan PT. BPR Bali Dananiaga di Kota Denpasar; 2). Kualitas layanan berpengaruh positif dan signifikan loyalitas nasabah. Hal ini berarti semakin baik kualitas layanan PT. BPR Bali Dananiaga, maka akan meningkatkan loyalitas nasabah PT. BPR Bali Dananiaga di Kota Denpasar; 3). Citra perusahaan berpengaruh positif dan signifikan loyalitas nasabah. Hal ini berarti apabila semakin bagus citra PT. BPR Bali Dananiaga dimata nasabah, maka akan meningkatkan loyalitas nasabah PT. BPR Bali Dananiaga di Kota Denpasar; 4). Citra perusahaan mampu memediasi hubungan kualitas layanan terhadap loyalitas nasabah secara signifikan. Adapun 
I Made Deddy Saputra, Pengaruh Kualitas Layanan terhadap...

mediasi yang terjadi pada model penelitian ini bersifat parsial, yang berarti bahwa variabel citra perusahaan berfungsi untuk menjembatani pengaruh kualitas layanan terhadap loyalitas nasabah BPR, tanpa merubah signifikansi pengaruh kualitas layanan terhadap loyalitas nasabah pada saat memasukkan variabel citra perusahaan kedalam model persamaan regresi. Hal ini berarti bahwa citra perusahaan yang terbentuk pada PT. BPR Bali Dananiaga turut mempengaruhi kualitas layanan terhadap loyalitas nasabah PT. BPR Bali Dananiaga di Kota Denpasar.

Saran yang dapat diberikan berkaitan dengan penelitian ini sebagai bahan pertimbangan serta masukan yang berguna bagi manajemen PT. BPR Bali Dananiaga untuk selanjutnya meningkatkan loyalitas nasabah manajemen PT. BPR Bali Dananiaga hendaknya meningkatkan kualitas layanan yang diberikan kepada nasabah dengan skor rata-rata terendah sebesar 3,83 dengan menyediakan fasilitas fisik yang lebih memadai di PT. BPR Bali Dananiaga. Untuk meningkatkan loyalitas nasabah manajemen di PT. BPR Bali Dananiaga hendaknya dapat mengelola citra perusahaan dimata nasabah dengan skor rata-rata terendah sebesar 4,09 dengan meningkatkan kepercayaan nasabah bahwa reputasi PT. BPR Bali Dananiaga adalah yang paling baik dari BPR yang lain.

Kemudian untuk memaksimalkan loyalitas nasabah sebaiknya manajemen di PT. BPR Bali Dananiaga dapat membuat mesin ATM (Anjungan Tunai Mandiri) akan membuat nasabah semakin mudah dalam bertransaksi dan sekaligus akan berdampak pada citra perusahaan. Bagi peneliti selanjutnya, diharapkan untuk melakukan penelitian dengan cakupan yang lebih luas seperti: 
mencari lokasi penelitian selain PT, menggunakan sampel penelitian yang lebih banyak, menambah variabel-variabel lain diluar penelitian ini, menggunakan teknik analisis data yang berbeda (PLS atau SEM), serta diharapkan mampu menambah refrensi terhadap variabel yang akan diteliti.

\section{DAFTAR RUJUKAN}

Anggrayana, Dewa Putu Gede Wedha \& Komang Agus Satria Pramudana. 2013. Pengaruh Kualitas Layanan Terhadap Kepuasan Pelanggan dan Loyalitas Pelanggan Pada UD. Dewa Putu Toris Gianyar. E-Jurnal Manajemen Unud, 2(10): 1346-1360.

Arab, M., SM Ghazi Tabatabei., A Rashidian., A Rahimi., Forushani., dan E Zarei. 2012. The Effect of service Quality on Patient Loyalty: a Study of Private Hospitals in Tehran, Iran. Iranian J Publ Health, 41(9), pp: 71-77.

Boon-liat Cheng dan Zabid. 2013. Service Quality and the Mediating Effect of Corporate Image on the Relationship between Customer Satisfaction and Customer Loyalty in the Malaysian Hotel Industry, Gadjah Mada International Journal of Business Vol. 15, No. 2 (May - August 2013): 99 $-112$

Ferdinand, 2013. Metode Penelitian Manajemen:Pedoman Penelitian untuk Skripsi, Tesis dan Disertai Ilmu Manajemen. Semarang: Universitas Diponogoro.

Hadiyati, E. 2010. Analisis Kualitas Layanan dan Pengaruhnya terhadap Loyalitas Nasabah (Studi Kasus pada PT. Pos Indonesia (Persero) Kantor Pos Lawang). Jurnal Manajemen Universitas Jambi, 2(2): 81-90.

Hair, J.F., William C. Black., Barry J. Babin \& Rolph E. Anderson. 2010. Multivariate Data Analysis. \&th edition. New York: Prentice Hall International Inc.

Handi, Erawan. 2013. Pengaruh Kualitas Layanan Terhadap Citra Perusahaan (Studi Kasus: Pt Living Social). Skripsi Jurusan Marketing Communication, School of Communication, Bina Nusantara University Jakarta Barat.

Hidayat, C. 2010. Pengaruh Kualitas Layanan dan Produk Terhadap Citra Perusahaan dan Loyalitas Nasabah. Jurnal Manajemen. 
I Made Deddy Saputra, Pengaruh Kualitas Layanan terhadap...

Rachmad. 2009. Pengaruh Kualitas Layanan, Kualitas Produk dan Nilai Nasabah terhadap Kepuasan dan Loyalitas Nasabah Bank Mandiri. Jurnal Manajemen: 59-72.

Hilmawan, Made Irvan. 2014. Pengaruh Kualitas Layanan terhadap Loyalitas melalui Kepuasan Konsumen Studi pada Trans Sarbagita. E-jurnal Manajemen, 3(4): 1005-1021.

Kertajaya, Hermawan. 2013. Tourism Marketing 3.0. Jakarta: PT Gramedia Pustaka Utama.

Korn, Henry Alphonse. 2013. Studi Mengenai Pengaruh Kualitas Layanan dan Kualitas Produk terhadap Kepuasan Nasabah untuk Meningkatkan Loyalitas (Studi pada Nasabah Tabungan Bank CIMB Niaga Pemuda Semarang). Jurnal Sains Pemasaran Indonesia, XII: 261-282.

Kotler, Philip. 2013, Marketing Management. Edisi Milenium. New Jersey: Prentice Hall Intl.

Lovelock, Christopher., Jochen Wirtz., Jacky Mussry. 2012. Pemasaran Jasa. Edisi 7. Jakarta: Erlangga.

Mosahab, R., Mahamad, O., Ramayah, T. 2012. Service quality, customer satisfaction and loyalty: A test of mediation. Journal International Business Research,3(4): 72-80.

Normasari, Selvy., Srikandi Kumadji, Andriani Kusumawati. 2013. Pengaruh Kualitas Layanan Terhadap Kepuasan Pelanggan, Citra Perusahaan dan Loyalitas Pelanggan. Jurnal Administrasi Bisnis (JAB) | Vol. 6 No. 2

Pemayuni, Wina., dan Wulandari. 2015. Peran Corporate image Dalam Memediasi Pengaruh Corporate Social Responsbility Terhadap Purchase Intention Air Minum Dalam Kemasan. E-Jurnal Manajemen Unud, Vol. 4, No. 6, 2015: 1574-1590 ISSN: 2302-8912

Porral, Cristina Calvo \& mark F Lang. 2015. Private Labels: The role of Manufacturer Identification, brand loyalty and image on purchase intention. British food Journal, 117(2) pp: 506-522.

Pramana, I Gede Yogi \& I Made Rastini. 2016. Pengaruh Kualitas Layanan terhadap Kepercayaan Nasabah dan Loyalitas Nasabah Bank Mandiri cabang Veteran Denpasar Bali. E-Jurnal Manajemen Unud, 5(1): 23028912.

, I Kadek Bayu. 2017. Peran Kepercayaan Nasabah dalam Memediasi Pengaruh Kualitas Layanan terhadap Loyalitas Nasabah. E-Jurnal Manajemen Unud 6(12): 6818-6844. 
Pratama, Gede Wibi Satya \& I Nyoman Nurcaya. 2016. Pengaruh Corporate Social Responsibility terhadap Ekuitas Merek yang di Mediasi oleh Citra Perusahaan. E-Jurnal Manajemen Unud, 5(7): 4253-4280.

Putri, Wurry Indah Sari. 2014, Pengaruh Kualitas Layanan Terhadap Kepuasan Konsumen serta Citra Perusahaan dalam Membangun Loyalitas Konsumen PT. KAI. E-Jurnal Graduate Unpar Part A ISSN: 23554304.

Riduwan \& Kuncoro. 2011. Cara Menggunakan dan Memakai Path Analysis (Analisis Jalur). Bandung: Alfabeta.

Saputra, Falla Ilhami. 2013. Kualitas Layanan, Citra dan Pengaruhnya terhadap Loyalitas melalui Kepuasan Pelanggan (Studi pada PT Bank BNI 46 Sentra Kredit Kecil Surabaya. Jurnal Aplikasi Manajemen, 11(3): 445457.

Sari, Novi Nur Indah., Achmad Fauzi., Sunarti. 2014. Pengaruh Corporate Social Responcibility (CSR) terhadap Citra Perusahaan (Survei pada Masyarakat yang bekerja di Pabrik Gula Kebon Agung yang bertempat tinggal di Daerah Kebon Agung Malang). Jurnal Administrasi Bisnis, 8(2): 1-7.

Satya, Wibi. dan Nyoman Nurcaya. 2016. Pengaruh Corporate Social Responsbility Terhadap ekuitas Merek Yang Dimediasi Oleh Perusahaan, E-Jurnal Manajemen Unud, Vol. 5, No.7, 2016: 4253 - 4280 ISSN : 2302-8912.

Sembiring, Inka Janita. 2014. Pengaruh Kualitas Produk dan Kualitas Layanan terhadap Kepuasan Pelanggan dalam Membentuk Loyalitas Pelanggan (Studi pada Pelanggan McDonald's MT Haryono Malang). Jurnal Manajemen, 9(2): 20-31.

Sugiyono. 2013. Metode Penelitian Manajemen. Bandung: Alfabeta.

Suratno, Aziz Fthoni., Andi Tri Haryono. 2016. Pengaruh Citra Perusahaan dan Kualitas Layanan Terhadap Loyalitas Pelanggan dengan Kepuasan Pelanggan sebagai variabel Intervening pada PT Pelabuhan Indonesia III Semarang. Jurnal of Management, Volume 2.

Tjiptono, Fandi. 2012. Pemasaran Strategik. Yogyakarta: ANDI.

Widiyanto dan Juan Suam Toro. 2012. Analysis Of Influence Of Service Quality And Price On Faieness With Customer Satisfaction Customer Loyalty, Corporate Image And Variable Trust As Mediation: Studies In Consumer $P O$. Rosalia Indah Surakarta. 
I Made Deddy Saputra, Pengaruh Kualitas Layanan terhadap...

Wu, Paul CS. 2011. The Effect of Store Image and Service Quality on Brand Image and Purchase Intention for Private Label Brands. Australian Marketing Journal 19 (2011).

Wungow, Richie. 2013, Kualitas Layanan, Citra, Nilai, dan Kepuasan Pengaruhnya terhadap Loyalitas Pelanggan. Jurnal EMBA Vol.1 No.3 ISSN:2303-1174. 